\title{
Analytical methods and simulation models to assess innovative operational measures and technologies for rail port terminals: the case of Valencia Principe Felipe terminal
}

\author{
Luigi Capodilupo \\ Sapienza University of Rome - DICEA, Italy \\ Salvador Furiò Pruñonosa \\ Fundacion Valenciaport, Spain \\ Cristiano Marinacci \\ Sapienza University of Rome - DICEA, Italy \\ Stefano Ricci \\ Sapienza University of Rome - DICEA, Italy \\ Luca Rizzetto \\ Sapienza University of Rome - DICEA, Italy
}

\begin{abstract}
The topic of freight transport by rail is a complex theme and, in recent years, a main issue of European policy. The legislation evolution and the White Paper 2011 have demonstrated the European intention to re-launch this sector. The challenge is to promote the intermodal transport system to the detriment of road freight transport. In this context intermodal freight terminals, play a primary role for the supply chain, they are the connection point between the various transport nodes and the nodal points where the freight are handled, stored and transferred between different modes to final customer. To achieve the purpose, it is strengthen the improvement of existing intermodal freight terminals and the development of innovative intermodal freight terminals towards higher performance (ERRAC, 2012). Many terminal performances improvements have been proposed and sometime experimented. They are normally basing on combinations of operational measures and innovative technologies (e.g. automatic horizontal and parallel storage and handling, automated gate and sensors for tracking systems data exchange) tested in various terminals, with oftencontradictory results. The research work described in this paper (developed within the Capacity4Rail EU project) focusses on the assessment of effects that these innovations can have in the intermodal freight terminals combined in various alternative consistent effective scenarios. The methodological framework setup to assess these innovations is basing on a combination of analytical methods based on sequential algorithms and discrete events simulation models. The output of this assessment method are key performance indicators (KPIs) selected according to terminals typologies and related to different aspects (e.g. management, operation and organization). The present paper illustrates the application of the methodological framework, tuned on the operation of various intermodal terminals, for the validation on today operation and the assessment of possible future scenarios to the case study of the Principe Felipe sea-rail terminal in Valencia.
\end{abstract}




\section{INTRODUCTION}

With the publication of the White Paper on European Transport 2011, the European Commission recently adopted a comprehensive strategy for a competitive transport system that can increase mobility; remove major barriers in essential areas and faster growth and employment. The rail freight system is part of this strategy; the main target is to shift freight from road to more sustainable modes for distances over $300 \mathrm{~km}: 30 \%$ by 2030 and $50 \%$ by 2050. In this context, intermodal freight terminals play a primary role for the supply chain and the achievement of the planned objectives of the EC, also depending on the increasing of their performances. The introduction of new technologies and innovative operational measures will be central element of future freight terminals. In this work are presented different technologies and operational measurements combined into two different scenarios for a rail-sea future terminal. Moreover, two different methodological and general approaches (assessment methods) allows evaluating the incremental terminal performances by Key Performance Indicators (KPIs) setup according to terminals typologies. Finally, in addition to the illustrated methodological framework, a real case study includes the intermodal sea-rail terminal in Valencia Principe Felipe.

\section{INNOVATIVE OPERATIONAL MEASURES AND TECHNOLOGIES}

An accurate research on the existing technologies in the intermodal freight rail-sea terminals allowed defining the common standard and to assume a possible system change, composed of innovative operational measures and technologies, that could constitute the standard of far future long term freight terminals (Table 1) (Islam D. et al., 2015). However, the described methods and system changes cannot predict the real behavior of market participants in the future, mainly influenced by commercial effects. The model shows what could happen if relevant operational measures and innovations are in line with proposed terminal operations.

\section{ASSESSMENT METHODS, STRUCTURE AND PERFORMANCES}

In this section, analysis and simulation tools-based methods are illustrated. They evaluate technological innovations and operative measures in future rail freight terminals. The main goal was to build and propose generalized and adaptable methods to evaluate different kinds of freight terminals.

\subsection{Analytical method}

Operative times in the terminal represent the main indicators to evaluate their performances and key components to quantify costs. Their quantitative analysis is a strategic activity, both in the design and operation of the terminal and the organization of the entire logistics chain. 


\begin{tabular}{|c|c|c|}
\hline & COMMON STANDARD & SYSTEM CHANGE (2050) \\
\hline Handling typology & - Indirect and direct & - Faster and fully direct \\
\hline $\begin{array}{l}\text { Handling equipment in } \\
\text { operative track }\end{array}$ & $\begin{array}{l}\text { - Transtainer, reach stacker } \\
\text { or forklift } \\
\text { - Few systems for } \\
\text { horizontal transfer }\end{array}$ & $\begin{array}{l}\text { - Automated fast transtainer } \\
\text { with moving train } \\
\text { - Automated systems for } \\
\text { horizontal/parallel handling }\end{array}$ \\
\hline $\begin{array}{l}\text { Handling equipment, } \\
\text { positioning and grab }\end{array}$ & $\begin{array}{l}\text { - Manual with/without } \\
\text { support technologies }\end{array}$ & - Automated \\
\hline $\begin{array}{l}\text { Handling equipment for } \\
\text { vertical handling }\end{array}$ & $\begin{array}{l}\text { - Spreader (twist lock / } \\
\text { grapple arms) } \\
\text { - Intermodal spreader } \\
\text { (twist lock / grapple arms) }\end{array}$ & $\begin{array}{l}\text { - Intermodal complex } \\
\text { spreader (multiple ITU } \\
\text { handling) }\end{array}$ \\
\hline $\begin{array}{l}\text { Handling layout: track } \\
\text { operative length }\end{array}$ & $-550 \div 850 m$ & $-1000 \div 2000 m$ \\
\hline $\begin{array}{l}\text { Terminal access - ICT } \\
\text { technologies: ITU/Vehicle } \\
\text { identification and } \\
\text { transport data exchange }\end{array}$ & - Manual control & $\begin{array}{l}\text { - Automatic control } \\
\text { (automatic gate) }\end{array}$ \\
\hline Internal moving vehicles & $\begin{array}{l}\text { - Slow with loco change } \\
\text { (electrical to diesel). }\end{array}$ & $\begin{array}{l}\text { - Fast without loco change } \\
\text { locomotive } \\
\text { - Hybrid locomotive }\end{array}$ \\
\hline Terminal Working period & $\begin{array}{l}\text { - Less than h 24/7 days per } \\
\text { week }\end{array}$ & $\begin{array}{l}\text { - h 24/ } 7 \text { days per week } \\
\text { (optimal neighborhood } \\
\text { conditions) }\end{array}$ \\
\hline
\end{tabular}

Table 1 - Identified innovative operational measures and technologies for a generic rail-see intermodal terminal

The used analytical method permits to quantify the ITUs and vehicles Total Transit Time (TTR) within a rail-sea terminal formalizing all the operations, split into operational phases (OP, deterministic component) and waiting phases (WP, aleatory component).

Its formulation is generalizable as follows (Ricci S., 2014):

$$
T T R=T E(C, O)+T I(T, D, R)
$$

Where:

1) $T E$ depends on infrastructures and transport services external to the terminal: Capacity $(\mathrm{C})$ and operative planning of external services $(O)$;

2) TI depends on infrastructural and technological equipment, as well as operative organization of the terminal: operative planning of the terminal $(T)$, terminal size $(D)$, operative requirements and regulations $(R)$.

The individual activities include operative phase $(O P)$ and a previous waiting phase $(W P)$ and the corresponding durations: operative time $(O T)$ and waiting time $(W T)$. 
The building process of the model is summarized in flow-chart of figure. 1 .

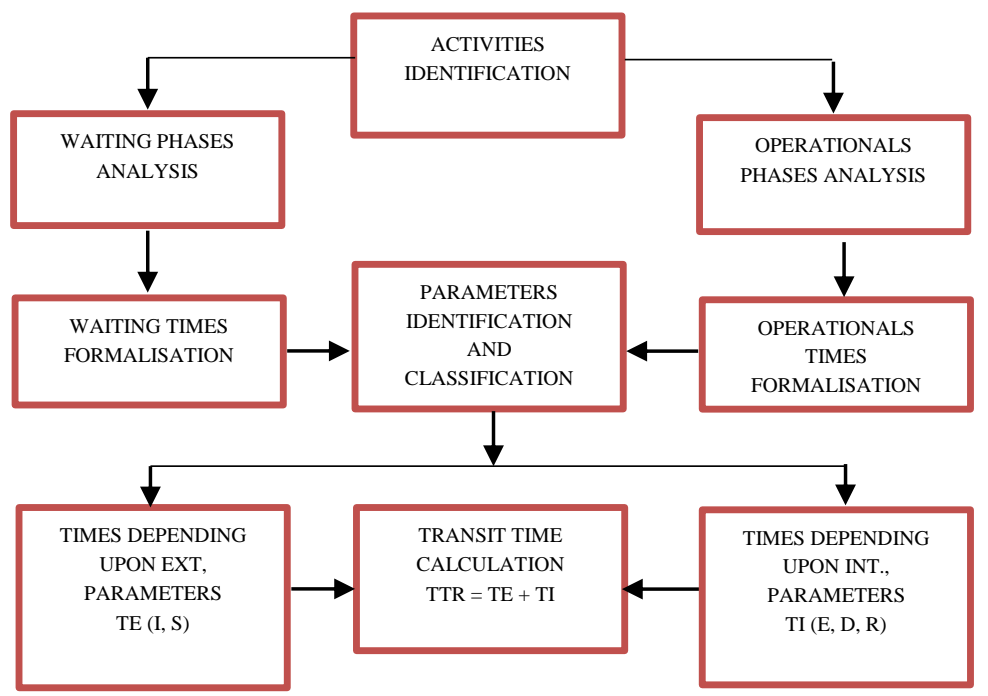

Fig. 1 - Analytical method construction process flow-chart

The typologies of activities are movements on-board a vehicle (train or ship), transfer from/to vehicles and stocking area (in case of indirect transfer) and waiting for the following activity on-board or in the stocking area itself.

The formalization of time calculation is:

$$
T_{O G}=\sum_{i=1 \ldots 5} T_{W i}+\sum_{j=1 \ldots 2} T_{O V i}+\sum_{k=1 \ldots p} T_{O L k}
$$

In addition to the five waiting phases inside the terminal, the operational activities include again two on-board movements (respectively on train and ship) and two loading/unloading activities, respectively in the yard and on the quay.

\subsection{Simulation model}

In the general framework of container terminal simulators (Bielli et al., 2006) (Gudelj et al., 2003), (Iris et al., 2003), the simulation model here presented, is using the freeware Planimate $®$. It allows the construction of discrete-event micro simulation models. Thanks to its flexibility, it is particularly suitable for the simulation of complex systems, which use large amounts of data and sub-processes, ensuring easy monitoring of the system evolution. The model allows to represent and reproduce the operations in the terminal and to obtain large set of outputs concerning flows (vehicles and ITUs), timing, procedures and layout, identifying the critical processes (Baldassarra A. et al., 2010) (Malavasi G. et al, 2006). Moreover, the model permits to quantify the effects of possible implementations of new technologies or operational measures. The model building process in Planimate $\AA$ includes four main phases related to design objects, flows, interactions and graphics.

The result of these phases is a multiple graphic representing static properties of the system, while dynamic properties correspond to net operative rules, in particular: 
- An event occurs as soon as all the pre-conditions are enabled;

- The occurrence of an event disables the pre-conditions and enables the post-conditions. The active conditions represent the state of the system, while the items represent its evolution. They can move through the objects of the net using paths, which represent a logical sequence of events. Once the objects are fixed, it is possible to build up paths, which permit items to move among the objects building successions defining the evolution of the system. For each class of items, it is possible to define an animated sequence of steps during a simulation: the set of paths is the flow in which, during the simulation, one or more items can move simultaneously.

The model, specialised for a rail-sea terminal, simulates a generic container terminal in a port and includes various subnetworks, which reproduce all the functions to operate the plant. After the data collection carried out in the plant itself to design the specific simulation model, it is necessary to define the following items across the various subsystems:

- Train and ship: they bring and forward the containers to/from their final destination;

- Trailer: it is the vehicle carrying the containers from the quay to the storage and back;

- Reach stackers and straddle carriers: they are the vehicles handling containers in stocking areas;

- Transtainer: it is the device used for handling containers in the stocking area;

- Container itself.

The model includes multiple subsystems, reproduced by the Portals, representing a particular function performed within the terminal and providing with multiple output data. The process for building, calibrating and validating the model includes the typical steps summarized in the general scheme represented in Figure 2. After the validation, the model was ready for the application to project scenarios and the comparison of their performances.

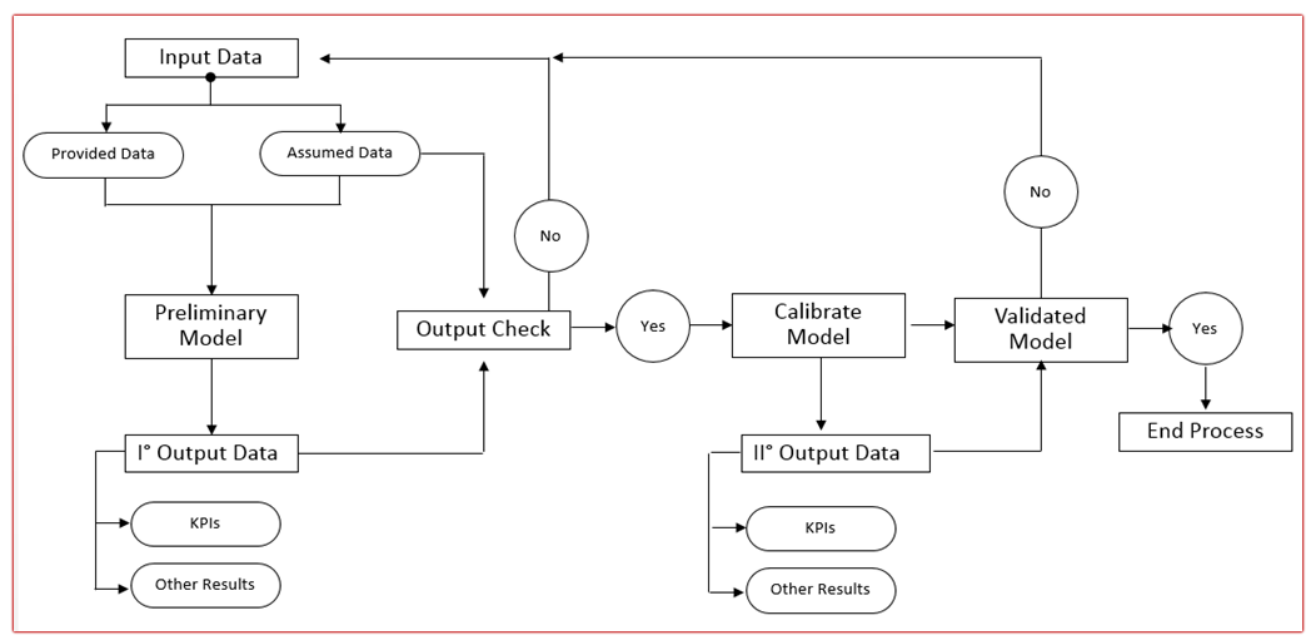

Fig. 2 - Stepwise process to build, calibrate and validate a generic simulation model

\section{Key performance indicators (KPIs)}

Method and model described above allow obtaining a large amount of data on terminal operations. 
In order to measure the performances at present and after the implementation of scenarios, it has been necessary to identify key performances indicators (KPI):

- Measurable by the proposed model;

- Capable to synthetize the terminal performances;

- Sensible to potential changes introduced by new technologies and innovation measures;

- Related to different aspects (management, operation, organization and terminal layout). They are:

- Total transit time for ITU and vehicles (ships and trains);

- Handling equipment utilization rate;

- Stored ITU rate;

- Energy consumption rates;

- Handling equipment performances;

- Handling equipment haul;

- Train waiting rate;

- Terminal occupancy;

- Maintainability index;

- Reliability index;

- Vehicles (ships and trains) utilisation rates;

- Personnel distribution rate.

The results presented in the following sections are only concerning the subset of these indicators more specifically defined in Table 2 .

\section{Case study}

The case study of the intermodal freight rail-sea terminal of Principe Felipe in Valencia port allowed validating the above detailed methodological framework.

The railway terminal of the dock Principe Felipe is located in the Southeast part of the public container terminal (Figure 3), characterized by:

- Total area: $50.000 \mathrm{~m}^{2}$;

- Loading/unloading area with four railway tracks;

- Extra railway tracks to perform the manoeuvres of the locomotive;

- Electrified railway tracks until the loading/unloading area;

- Two road access to the terminal;

- Two storage areas with 9,000 and $20,000 \mathrm{~m}^{2}$ respectively.

The loading and unloading processes equipment utilised do not operate exclusively in the railway terminal. The capacity of the railway terminal depends upon three main parameters: the arriving trains flow, the storage area in the railway terminal and finally the performances of the loading and unloading equipment and operations. According to several analysis carried out, the equipment is the limiting factor of the capacity in the railway terminal of the port of Valencia. The railway terminal is divided into two storage areas, where the containers are stacked (24h maximum) before they can be loaded on a train. 


\begin{tabular}{|c|c|c|c|}
\hline \multicolumn{2}{|r|}{ Definition } & Description & Dependences \\
\hline $\begin{array}{l}\text { Total } \\
\text { Transit } \\
\text { Time of } \\
\text { ITU (or } \\
\text { vehicle) }\end{array}$ & $T T R=\sum_{i=1}^{n} T W i+\sum_{i=i}^{n} T O i$ & $\begin{array}{l}\text { Time period from the arrival of } \\
\text { ITU (or vehicle) to terminal } \\
\text { gate from an external transport } \\
\text { infrastructure to the exit of ITU } \\
\text { (or vehicle) from the terminal } \\
\text { towards a different transport } \\
\text { infrastructure. } \\
\text {. } T T R_{v}=\text { vehicle total transit } \\
\text { time (train and ship) } \\
T T R_{I T U} \text { Unit total transit } \\
\text { time } \\
T W=\text { waiting time } \\
\text {. } T O=\text { operational time }\end{array}$ & $\begin{array}{l}\text { External } \\
\text { infrastructures } \\
\text { and transport } \\
\text { services } \\
\text { Technologies } \\
\text { Operational } \\
\text { rules } \\
\text { Terminal } \\
\text { dimensions }\end{array}$ \\
\hline $\begin{array}{l}\text { Equipment } \\
\text { Performan } \\
\text { ce }\end{array}$ & $E p=\frac{n I T U}{h}$ & 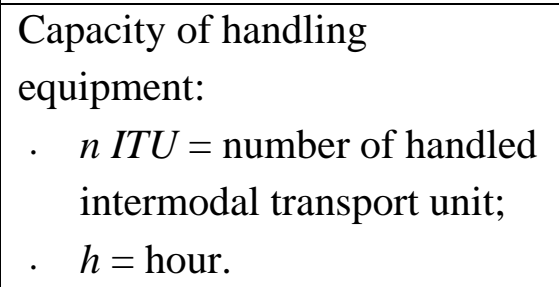 & $\begin{array}{l}\text { Handling } \\
\text { technologies }\end{array}$ \\
\hline $\begin{array}{l}\text { Vehicles } \\
\text { (ships and } \\
\text { train) } \\
\text { utilization } \\
\text { rate }\end{array}$ & $\varrho=\frac{\lambda}{\mu}$ & $\begin{array}{l}\text { Queueing theory parameters } \\
\text { define the correct sizing of } \\
\text { different sidings: } \\
\cdot \quad \varrho=\text { system utilization; } \\
\cdot \quad \lambda=\text { average rate of arrivals; } \\
\cdot \quad \mu=\text { average rate of served. }\end{array}$ & $\begin{array}{l}\text { External } \\
\text { infrastructures } \\
\text { and transport } \\
\text { services } \\
\text { Technologies } \\
\text { Operational } \\
\text { rules } \\
\text { Terminal } \\
\text { dimensions }\end{array}$ \\
\hline
\end{tabular}

Table 2. KPI used for the assessment of rail-sea intermodal terminal in Valencia port
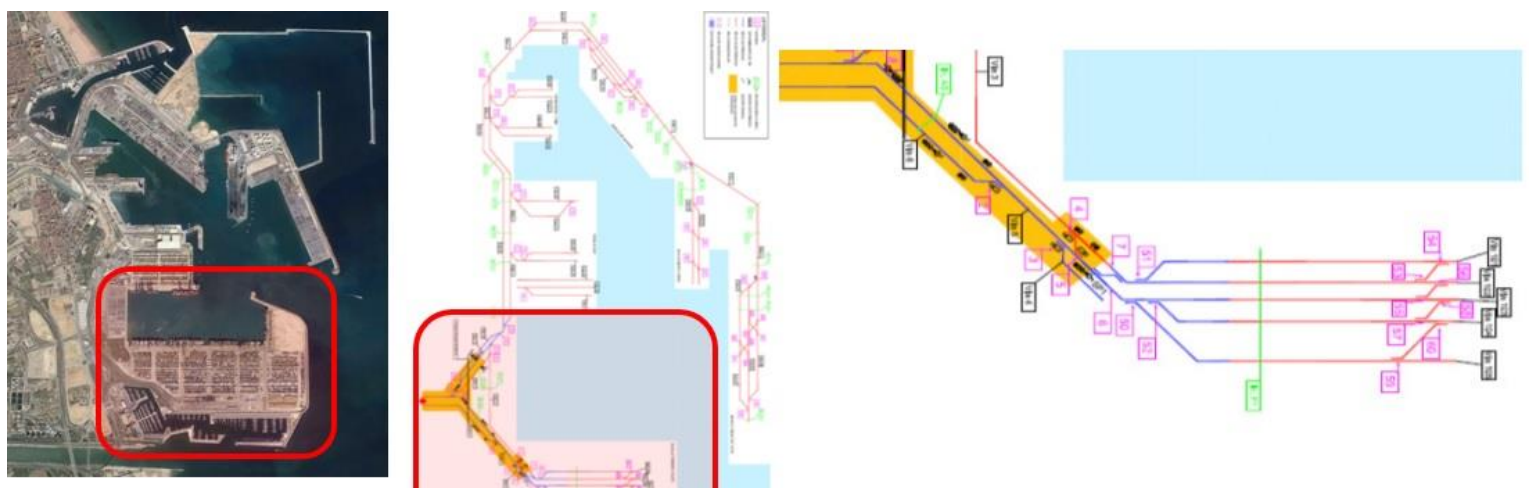

Fig. 3 - Layout of Principe Felipe rail terminal in Valencia port 
Once the train is in the assigned track, a RTG gets in the terminal and takes place over the four railway tracks leaving enough space for a truck. In general, containers loading and unloading operations require at least one RTG, one reach stacker and one trailer. Figure 4 shows a scheme of the loading/unloading process. The different steps followed in the operation are:

- Reach stacker picking the container from the storage area and dropping it over the trailer;

- Trailer moving the container and placing it near the train, below the RTG;

- RTG picking the container from the trailer and dropping it on the assigned train wagon.

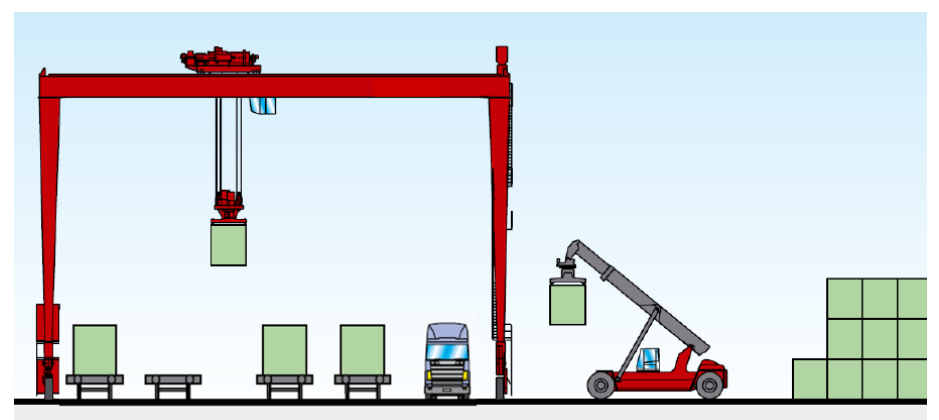

Figure 4. Loading and unloading process applied in the Valencia terminal

\section{Potential future scenarios and results}

After the validation, analytical method and simulation model are useful to assess innovative project scenarios (two of them qualified in Table 3) and to compare them with the state of art, analysing the variation of performances by means of KPI calculation.

\begin{tabular}{|c|c|c|}
\hline & SCENARIO 1 & SCENARIO 2 \\
\hline $\begin{array}{l}\text { Operational } \\
\text { measures }\end{array}$ & $\begin{array}{l}\text { - } \text { Faster and full direct handling } \\
\text { - } \text { Automatic ITU/Vehicle } \\
\text { control and data exchange } \\
\text { - } \quad \text { No locomotive change } \\
\text { - Long train } \\
\text { - } 24 \text { h working period }\end{array}$ & $\begin{array}{l}\text { - Horizontal and parallel } \\
\text { handling } \\
\text { - } \quad \text { Faster and full direct handling } \\
\text { - } \quad \text { Automatic ITU/Vehicle } \\
\text { control and data exchange } \\
\text { - } \quad \text { No locomotive change } \\
\text { - } \quad \text { Long train } \\
\text { - } 24 \text { h working period }\end{array}$ \\
\hline Technologies & $\begin{array}{l}\text { - } \text { Duo loco } \\
\text { - Automated gate } \\
\text { - } \quad \text { Automated fast transtainer } \\
\text { - Intermodal complex spreader }\end{array}$ & $\begin{array}{ll}\text { - } & \text { Duo loco } \\
\text { - } & \text { Automated gate }\end{array}$ \\
\hline
\end{tabular}

Table 3. Project scenarios including innovative operational measures and technologies

The graphics in figures $5 \div 8$ show the main results achieved in terms of KPI by means of the most reliable methods: analytical method for the calculation of the transit time and simulation model for the calculation of equipment performances and vehicles' utilization. 


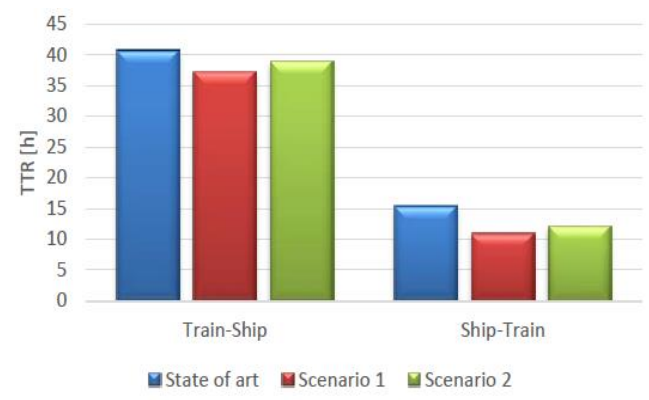

Figure 5. ITU transit time calculated by analytical method

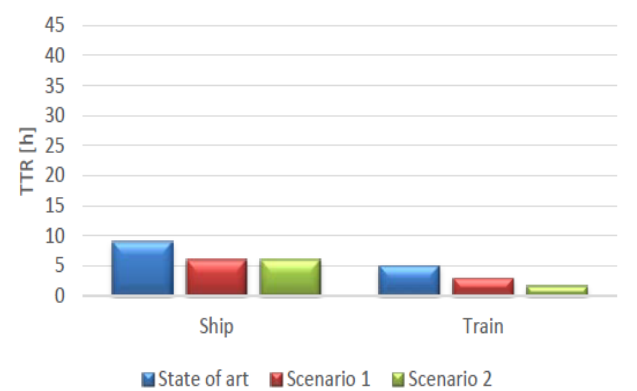

Figure 6. Vehicles transit time calculated by analytical method

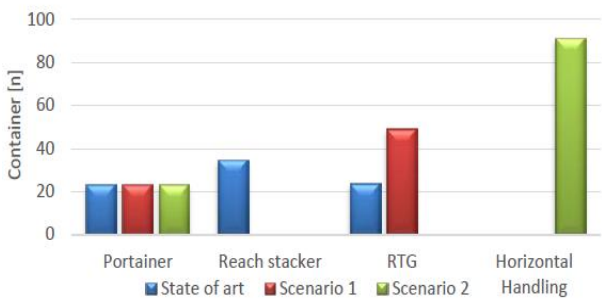

Figure 7. Equipment performances calculated by simulation model

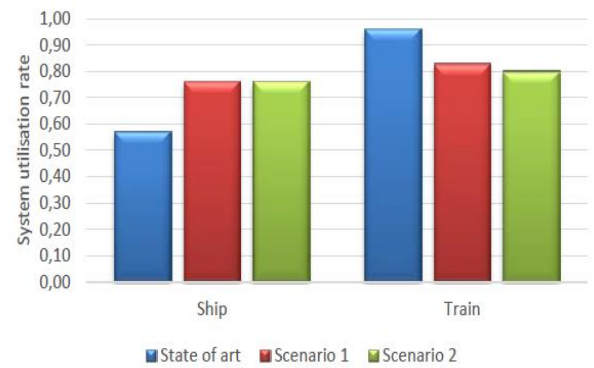

Figure 8. Vehicles utilisation rate calculated by simulation model

By analysing the results of analytical method and simulation model obtained by using the present common standards and the future technologies and operational measures included in Scenarios 1 and 2, it is possible to derive the following highlights for the case study terminal:

- Not negligible reductions of ITUs transit time in train-ship direction: $10 \%$ in Scenario 1 and $5 \%$ in Scenario 2; 
- More important reductions of ITUs transit time in ship-train direction: $31 \%$ in Scenario 1 and $25 \%$ in Scenario 2;

- Relevant reductions of vehicles transit time:

- $33 \%$ in Scenario 1 and $44 \%$ in Scenario 2 for ships,

- $\quad 50 \%$ in Scenario 1 and $80 \%$ in Scenario 2for trains;

- Huge increase of maximum equipment performances: 78\% in Scenario 1 (by RTG) and $246 \%$ in Scenario 2 (by horizontal handling);

- Important increase of ships utilisation rate: $32 \%$ in both scenarios;

- Moderate decrease of train utilisation rate: 13\% in Scenario 1 and 16\% in Scenario 2;

- Scenario 1 more easily implementable: less infrastructural adjustments required.

\section{Final remarks}

\subsection{Conclusions on case study}

New technologies and innovative operational measures extensively demonstrated their capability to improve the terminal performances. A more structured approach is required to depict future effective rail freight terminals. Scenarios are a combination of innovations, evaluated using two different methodologies capable to deal with many typologies of terminals and to evaluate in advance the influence of implemented innovations. The KPI outputs demonstrate that innovations are able to increase the overall performances of a terminal, enabling an increase in flows, in terms of intermodal transport units and vehicles, as well as in a reduction of the duration of various operational phases, according to the objectives of the European Union.

\subsection{Conclusions on methodology}

The analytical method and the simulation demonstrated a wide applicability and a relevant potential for the use by terminals planners and operators thanks to their capacity to allow the potentials of infrastructures and equipment. The next methodological step will be the integration of isolated models (shunting terminal, quay terminal, etc.) into a system, so that the whole rail infrastructure in a port can be analysed. Proposed methods and models could be also useful for the design of the railway infrastructures of future extensions of the port.

\section{REFERENCES}

BALDASSARRA A., IMPASTATO S., RICCI S. (2010). Intermodal terminal simulation for operations Management. European Transport. Trasporti Europei n. 46: pp. 86-99.

BIELLI M., BOULMAKOUL A., RIDA M. (2006). Object oriented model for container terminal, distributed simulation. European Journal of Operational Research, Vol. 175, No. 3, pp.,1731-1751, ISSN 0377-2217.

ERRAC (2012). Encouraging modal shift (long distance) and decongesting transport corridors. Freight Roadmap. Work Package 2. 
GUDELJ A., KRČUM M., TWRDY E. (2003). Models and Methods for Operations in Port Container Terminals, Promet - Traffic \& Transportation, Vol. 22, 2010, No. 1, 43-51.

IRIS F.A.V., DE KOSTER R. (2003). Transshipment of containers at a container terminal: An overview. European Journal of Operational Research 147 PP. 1-16.

ISLAM D., RICCI S., NELLDAL B. (2015) State-of-the-art European rail freight system and future needs. Rail Newcastle conference, Newcastle University.

MALAVASI G., QUATTRINI A., RICCI S. (2006) Effect of the distribution of the arrivals and of the intermodal units' sizes on the transit time through freight terminals. In Computer System Design and Operation in the Railway and other Transit Systems. Computer in Railways X. WIT Press, Southampton.

RICCI S. (2014). Systematic approach to functional requirements for future freight terminals. Transport research Arena, Paris, 2014. 